CURRENT RESEARCH JOURNAL OF PHILOLOGICAL SCIENCES

(ISSN -2767-3758)

VOLUME 03 ISSUE 01 Pages: 96-100

SJIF IMPACT FACTOR (2021: 5. 823)

OCLC - 1242423883 METADATA IF - 6.925

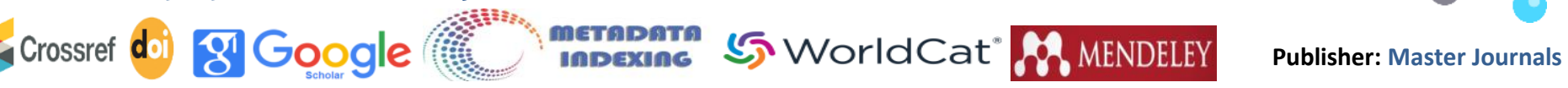

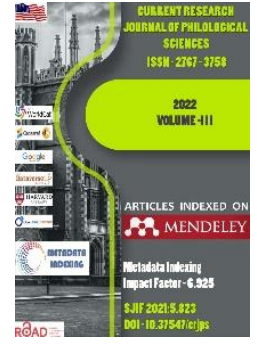

Journal Website: https://masterjournals. com/index.php/crips

Copyright: Original content from this work may be used under the terms of the creative commons attributes 4.0 licence.
Research Article

\section{THE DENOTATIVE COMPONENT OF SPEECH AND SOUND HARMONY}

Submission Date: January 11, 2022, Accepted Date: January 21, 2022,

Published Date: January 31, 2022

Crossref doi: https://doi.org/10.37547/philological-crjps-03-01-16

Khurshida Mashrapova

Independent Researcher Of The Faculty Of Uzbek Philology, Fergana State University, Uzbekistan

\title{
ABSTRACT
}

Phonological system helps to define the oppositions of phonemes, such as resonant-sound, lip-tongue-throat, and explosive sliding. Phonemes perform their social function in speech based on these distinguishing features. The method of formation of the speech sound represents a certain character in the speech process according to the presence of the sound, the vocal cords. This article discusses the denotative component of speech and sound harmony.

\section{KEYWORDS}

Phonemes, speech, sounds, function, formation of speech, denotative component of speech.

\section{INTRODUCTION}

Just as all things and events in existence are distinguished by their contrast, so are the sounds in language differentiated by oppositions. N.S. Trubetskoy says that the main foundation of the theory of phonology is based on the concept of "opposition" (or opposition). [1:36] As a result, we see the systematic arrangement of phonemes according to these characteristics.

The following phonological system helps to define the oppositions of phonemes, such as resonant-sound, liptongue-throat, and explosive sliding. Phonemes perform their social function in speech based on these 


\section{CURRENT RESEARCH JOURNAL OF PHILOLOGICAL SCIENCES}

(ISSN -2767-3758)

VOLUME 03 ISSUE 01 Pages: 96-100

SJIF IMPACT FACTOR (2021: 5. 823)

OCLC - 1242423883 METADATA IF - 6.925

\section{Crossref

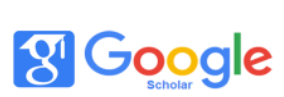

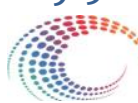

metapata

5) WorldCat

Publisher: Master Journals

distinguishing features. This is where the connection between phonetics and phonology comes into play. The place, method of formation of the speech sound represents a certain character in the speech process according to the presence of the sound, the vocal cords. In primitive words that are actively used in our speech, we see that phonemes are involved not only as a sign serving to differentiate meaning, but also as an independent sign with a certain semantics.

\section{MATERIALS AND METHODS}

The denotative component of the word and the presence of harmony on the sound side appear

For example: The phoneme "B" is a lip, explosive, resonant consonant sound. In the lexeme, the phoneme "B" represents the semantics "strong", "big", "first" according to the above signs. M: grandfather, giant, tall, one, brave, bek, bull, shout, head. In these places, the meaning of the phoneme "B" is based on the signs "explosive", "resonant". It is also located first, at the front as a member of the lab speech. It also makes sense in this case. For example: pervy, today, ben (me), spring, head, as a child.

The phoneme "P" is a lip-smacking, explosive, voiceless consonant sound, which expresses meaning in these respects. Depending on the state of the lab, the phoneme "P" produces the "closed" semaphore. For example: cover, bag, ball. In words such as cotton, popuk, pistachio, cocoon, supur, par, oppoq, picha, it means according to the state of "soundlessness". The "T" phoneme is an explosive, voiceless consonant. It is formed when the tongue strikes the tooth straight, upright, hard. The phoneme " $\mathrm{T}$ " means in this case . For example: straight, hard, flat, poplar, iron, comb, tooth, tongue, bottom, top, round, stone. This phoneme is involved in the words stone, tooth, hard, according to the state in which the tongue is tightly attached to the tooth.

The "N" phoneme is a prepositional, nasal, sonorous, explosive, resonant consonant that expresses meaning according to these characteristics. As a result of the delicate touch of the tongue to the teeth, "elegant" and "delicate" semantics are formed. For example: elegant, flute, delicate, what, flirt.

The "S" phoneme is a sliding, slippery, voiceless consonant. It is one of the most used consonants in Uzbek language. This sound represents a sign according to the state of "sliding". For example: water, healthy, sluggish, milk, cold, oily, slow, hot, is, swim, slide, slide, hang, smooth, grow. In some words, it represents a character according to its linguistic nature. For example: you, you, ost, ust.

The "L" phoneme is a prepositional, sonorous, slippery, resonant side sound. The above symbols express meaning according to the sign of "side" sound, which is not found in other phonemes, that is, the movement of the tongue in a loop. For example: il, ilgak, kol, latif, lanj, lol, marrow, snake, root, ol, tol, mol, yol. These words mean "subtle", "elongated".

In general, each phoneme represents a specific character. In the lexeme "mountain" the phoneme " $t$ " represents the semaphore "vertical", the phoneme "o" "wide", "greatness", "g '" "unevenness", "roughness" to form a whole lexeme. In the lexeme "board", the phoneme " $\mathrm{t}$ " represents the semantics "flat", "vertical", "x" "sliding". In the lexeme "il" the phoneme " $\mathrm{i}$ " has a narrow meaning, the phoneme "I" has a side sound. The lexeme "Bobo" contains the semantics "head", "big". In the lexeme "Momo", the phoneme " $\mathrm{m}$ " represents the semantics of gentleness in the sonorous, explosive, resonant state, and the phoneme "o" represents the semantics of "latitude". 


\section{CURRENT RESEARCH JOURNAL OF PHILOLOGICAL SCIENCES}

(ISSN -2767-3758)

VOLUME 03 ISSUE 01 Pages: 96-100

SJIF IMPACT FACTOR (2021: 5. 823)

OCLC - 1242423883 METADATA IF - 6.925

\section{Crossref

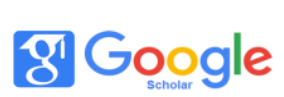

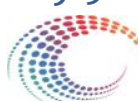

metapata

5. WorldCat fి̂ MENDELEY

Publisher: Master Journals

This means that speech sounds are not completely free in word structure. They verbally participate as the smallest unit of meaning, expressing the properties of the object. That is, "External world-objects, certain properties of events; The nerves in these organs affect the sensory organs, the nerves in the skin, the tongue with the taste, the nose with the smell, the color with the eyes, the ears with the vibration of the air, with their heat and cold. As a result, the brain acquires knowledge about the properties of objects, and their image is formed. "[2:12] So, the image of the properties of objects in the mind is a phoneme. For example, in the word "q" it means "deep" through the tongue, "o" means wide, "p" means silent, lab-lab, that is, according to the sign of closure.

It seems that the appearance of speech sounds is related to the process of perception, intuition. This idea is related to the original words used in the ancient Turkic languages. 'liq. Therefore, in primitive words, there seems to be a balance between the sound of speech and the meaning of the word. The root words are still actively used, the main meaning is assigned to the 1st, 2nd, 3rd phoneme in the lexeme. Because "The phonetic structure of single-syllable words in the All-Turkic and Old Turkic languages is mainly in the form $\mathrm{V}+\mathrm{C}+\mathrm{V}, \mathrm{V}+\mathrm{C}+\mathrm{C}, \mathrm{C}+\mathrm{V}+\mathrm{C}, \mathrm{C}+\mathrm{V}+$ $C+C$, in which the $C+V+C$ structure is comprehensive. This situation is fully preserved in modern languages, including Uzbek. This indicates that the phonetic structures of the single-syllable words used in our modern language are almost the same as they were in the ancient Turkic language. "[3:12] Orhun - According to Z. Akilbekova, K. Ashuraliyev, B. Osmonaliyeva, S. Sidikov, who compiled glossaries of total words in the sources studied in Enasoy's writings, there are 1680 original words, 749 of which are single syllables. zlardir. 560 of these words are actively used in modern Uzbek literary language. "[3: 9]

In the history of Turkic languages, many words are based on single syllables, and then the connection between the stem and the affix is broken. " has been mentioned many times in historical and etymological research. [4:15]

Hence, the $C+V+C$ structure is specific to Turkic languages, and the basic meaning of the lexeme is expressed in these 3 phonemes.

We can also see that in words that differ in a sound, the phoneme participates as a unit with a certain meaning. For example: lake-road, ol-il, tur-sur.

Another example: The alternation of "g" and " $y$ " in the words "raisins" and "raisins" provided the formation of a new meaningful word. The reason for this exchange is also explained "[5:9]

In this respect, the orange-phonemic deep backsliding, according to the jaranglilik character. This is the sound of flour with the participation of the wire deep in the back part of the air caused by uneven sliding. These criteria phonemic "uneven" and "rough" In chart form. "Y" -fonemasi- language school, earrings, Sonora, resonating sound. Output from the spread between the ground and the middle of the palate, slid formed. According to the "softness", "yoyiluvchanlik" scheme. The shell of "hard" and "rough" budirlik scheme, mayiz- "soft" scheme. $G$ and fonemalarining exchange, according to a new term motivations.

When we talk about the specific nature of language, we are also struck by the occurrence of the same, similar words in non-related languages, which in recent years have caused controversy in world linguistics. " It sounds harsh. It is as if the meaning is 


\section{CURRENT RESEARCH JOURNAL OF PHILOLOGICAL SCIENCES}

(ISSN -2767-3758)

VOLUME 03 ISSUE 01 Pages: 96-100

SJIF IMPACT FACTOR (2021: 5. 823)

OCLC - 1242423883 METADATA IF - 6.925

\section{Crossiet do

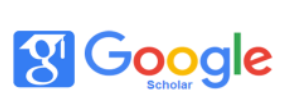

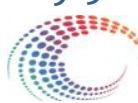

meTลDดTล

ST WorldCat

Publisher: Master Journals

hidden in the melody. This hard-sounding word means to cut, to cut. A word that is strictly word-cut. Interestingly, in English, cutting is also called "kat". What is the reason for the harmony in these three languages, which have no kinship?" or the Uzbek word "yemak" and the Russian word "yest" have the same root - ye. When we say "eat," the Russians say "eat ." [6:79] The phoneme " $t$ " represented a sign according to the feature of the tongue hitting the tooth hard. In the words "ye", "yesh", too, the sound " $y$ " has a meaning according to the sign of sliding.

Christian Vichmann, a linguist at the University of Leiden in the Netherlands, who has analyzed more than 6,000 languages and dialects, says he has also found signs of a connection between sound and meaning. and " $m$ ". This is somewhat similar to "um um." For example, in East Africa, the word "mumi" means chest. The results contradict the old philosophy of language. Until now, linguists believe that there is no connection between the sound and the meaning of a word. "[7]

Morten Kristiansen, a professor of children's language at Orchis University in Denmark, also points out that there is a connection between a word and its meaning. He says that the words "red" and "nose" are similar in several languages, and that the word "nose" has the sound "b" in all languages. [8]

Such similarities in non-related languages are very common. This is because the phoneme participates in the lexeme structure as a unit of meaning. According to the German linguist Wilhelm von Humboldt, "The diversity of languages is not only the result of the diversity of sounds, but also the difference in the way different nations look at the world."
In short, based on dialectical laws, the science of logic, theories of linguistics, we can say that speech sounds (phonemes) express a certain meaning in words in terms of acoustic-articulatory aspects. This harmony of sound and meaning can be seen in the analysis of single-syllable root words used in the ancient Turkic language, as well as those that are still actively used today. The occurrence of similar words between unrelated languages is also related to the physico-physiological aspect of speech sound. In general, the idea that linguistic unity is not completely free creates new perspectives in linguistics and opens the way to new research.

\section{REFERENCES}

1. Baskakov N., Sodiqov A., Abduazizov A. "General Linguistics". - Tashkent: Teacher 1979.

2. Khairullaev M., Khakberdiyev T. "Logic". Tashkent: Teacher, 2008.

3. ShodiyevF. "Structural-semantic-revival features of modern conjunctions"

4. RahmatullayevSh. "Etymological dictionary of Uzbek language" .- Tashkent: University, 2000.

5. Tojiev Y. "On the study of single-syllable words". Journal "Uzbek language and literature". Number 2. 201-abstract. Page 912.

6. Vohidov E. "Word subtlety". - Tashkent: Uzbekistan, 1998.

7. Oripova, G. (2019). UZBEK POETRY AND THE WORLD LITERATURE IN THE YEARS OF INDEPENDENCE. Scientific Journal of Polonia University, 32(1), 116-120.

8. Oripova Gulnoza Murodilovna. (2019). THE PECULIARITIES OF VAZN METER IN UZBEK POETRY OF THE INDEPENDENCE PERIOD. International Journal of Anglisticum.

\section{CONCLUSION}


CURRENT RESEARCH JOURNAL OF PHILOLOGICAL SCIENCES

(ISSN -2767-3758)

VOLUME 03 ISSUE 01 Pages: 96-100

SJIF IMPACT FACTOR (2021: 5 . 823)

OCLC - 1242423883 METADATA IF - 6.925

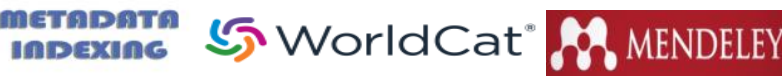

Publisher: Master Journals

Literature, Linguisitcs and Interdisciplinary Studies. Volume: 8 /Issue:2/. - Macedonia, 2019. -P.33-39.

9. Murodilovna, O. G. (2020). Melody and musicality in Lirycs. ACADEMICIA: An International Multidisciplinary Research Journal, 10(11), 656-664.

10. Oripova G. M., Tolibova M. T. Q. Composition Of Modern Uzbek Stories //The American Journal of Social Science and Education Innovations. - 2021. - T. 3. - №. 03. - C. 245249.

11. Oripova, G. (2020, December). RHYTHM AND MYTHING IN LYRICAL GENRE. In Конференции.

12. Oripova, G. (2019) "Traditions of folk ballads and distinctiveness of uzbek poetry of independence period," Scientific journal of the Fergana State University:Vol.2,Article12.

13. Sultanovna U. S. ARTISTIC PSYCHOLOGISM IN THE WORK OF S. RICHARDSON "PAMELA OR THE REWARDED VIRTUE". - 2020.

14. Sultanovna U. S. ARTISTIC AND PSYCHOLOGICAL BASES OF THE IMAGE OF A WOMAN IN THE LITERATURE //Journal of Critical Reviews. - 2020. - T. 7. - №. 9. - C. 247250.

15. Kaharov K. S. Formal and informal ways of conversation in the german and uzbek languages //ACADEMICIA: An International Multidisciplinary Research Journal. - 2020. - T. 10. - №. 9. - C. 286-289.

16. Iskandarova S. M., Kakharov K. S. THE ROLE OF NONVERBAL MEANS IN COMMUNICATION OF THE DIFFERENT NATIONS//The Way of Science. - 2014. - C. 45.

17. Холматов Ш., Йўлдошева М. ИНглИз ВА ЎЗБЕК ТИЛЛАРИДА СЎЗ УРҒУСИ ДАРАЖАЛАРИНИНГ АХАМИЯТИ ВА ЎЗИГА
ХОС ХУСУСИЯТЛАРИ //Academic research in educational sciences. - 2021. - T. 2. - №. 3.

18. Kosimov, A. (2021). THE IMPACT OF SELFEFFICACY IN ENHANCING ENGLISH PROFICIENCY AMONG UZBEK HIGH SCHOOL STUDENTS. British View, 6(1).

19. http s // sciencenordic.com

20. http s// sciencenordic.com 